\title{
Thermoanaerobacter subterraneus sp. nov., a novel thermophile isolated from oilfield water
}

\author{
Marie-Laure Fardeau, ${ }^{1}$ Michel Magot, ${ }^{2}$ Bharat K. C. Patel, ${ }^{3}$ \\ Pierre Thomas, ${ }^{1}$ Jean-Louis Garcia ${ }^{1}$ and Bernard Ollivier ${ }^{1,3}$
}

\footnotetext{
${ }^{1}$ Laboratoire de Microbiologie IRD, Universités de Provence et de la Méditerranée, ESIL case 925,163 Avenue de Luminy, 13288 Marseille cedex 9, France

2 Sanofi Recherche, Unité de Microbiologie, 31676 Labège,

France

3 School of Biomolecular and Biomedical Sciences, Faculty of Science, Griffith University, Brisbane, Queensland 4111, Australia
}

Author for correspondence: Bernard Ollivier. Tel: +334918285 76. Fax: +33491828570. e-mail: ollivier@esil.univ-mrs.fr
Keywords: thiosulfate reduction, Thermoanaerobacter subterraneus sp. nov., thermophile, phylogeny, oil well

\section{INTRODUCTION}

In the last two decades, intensive research on anaerobic, thermophilic, carbohydrate-fermenting micro-organisms from marine and terrestrial volcanic hot springs has led to the isolation of several new genera and species in the domains Bacteria and Archaea. The major rationale for this research stems from the biotechnological potential and the basic evolutionary traits of these microbes. In Bacteria, particular attention has been paid to members of the order Thermotogales and the family Thermoanaerobiaceae. The latter includes the genera Thermoanaerobacter and Thermoanaerobacterium, whose members reduce thiosulfate or elemental sulfur, respectively, to sulfide (Lee et al., 1993; Wiegel \& Ljungdahl, 1981). Thermoanaerobacter species are thermophilic, heterotrophic, saccharolytic anaerobes found in soil, faeces,

The GenBank accession number for the 16S rRNA gene sequence of strain SEBR $7858^{\top}$ is AF195797. sugar beet and sugar cane extraction juices, thermal spas, volcanic hot springs, non-volcanic geothermally heated subsurface aquifers, hydrothermal vents and oil-producing wells (Cayol et al., 1995; Cook et al., 1996; Jin et al., 1988; Kozianowski et al., 1997; Larsen et al., 1997; Lee et al., 1993; Leigh et al., 1981; Slobodkin et al., 1999; Wiegel, 1986; Wynter et al., 1996). Thermoanaerobacter species originating from oil-producing wells have only recently been studied and have been found to be similar to surface-inhabiting Thermoanaerobacter species (Cayol et al., 1995; Magot et al., 2000; Wynter et al., 1996). We report here on the characterization of a new member of this genus, Thermoanaerobacter subterraneus sp. nov., which was isolated from a French oilfield.

\section{METHODS}

Collection site. Strain SEBR $7858^{\mathrm{T}}$ was isolated from the 'Lacq Supérieur' oilfield located in south-west France. The in situ temperature of the geological formation, at a depth of $645 \mathrm{~m}$, was $52^{\circ} \mathrm{C}$. A water sample was aseptically collected 
at the wellhead, as described previously (Bernard et al., 1992), transported to the laboratory and stored at $4{ }^{\circ} \mathrm{C}$ until required.

Medium, enrichment and isolation. Enrichment and routine growth were performed using a culture medium containing $\left(1^{-1}\right): \mathrm{NH}_{4} \mathrm{Cl}, 1.0 \mathrm{~g} ; \mathrm{K}_{2} \mathrm{HPO}_{4} 0.3 \mathrm{~g} ; \mathrm{KH}_{2} \mathrm{PO}_{4}, 0.3 \mathrm{~g} ; \mathrm{MgCl}_{2}$ . $6 \mathrm{H}_{2} \mathrm{O}, 1 \cdot 0 \mathrm{~g} ; \mathrm{CaCl}_{2} \cdot 2 \mathrm{H}_{2} \mathrm{O}, 0 \cdot 1 \mathrm{~g} ; \mathrm{NaCl}_{1} 10 \cdot 0 \mathrm{~g} ; \mathrm{KCl}, 0 \cdot 2 \mathrm{~g}$; $\mathrm{Na}_{2} \mathrm{~S}_{2} \mathrm{O}_{3}, 3.16 \mathrm{~g}$; glucose, $20 \mathrm{mM}$; sodium thiosulfate, $20 \mathrm{mM}$; cysteine/ $\mathrm{HCl}, 0.5 \mathrm{~g}$; yeast extract (Difco), $2.0 \mathrm{~g}$; Bio-trypticase (BioMérieux), $2.0 \mathrm{~g}$; trace mineral element solution (Balch et al., 1979), $10 \mathrm{ml}$; resazurin, $1.0 \mathrm{mg}$. The $\mathrm{pH}$ was adjusted to $7 \cdot 0$ with $10 \mathrm{M} \mathrm{KOH}$ and the medium was boiled under a stream of $\mathrm{O}_{2}$-free $\mathrm{N}_{2}$ gas and cooled to room temperature. Five or $20 \mathrm{ml}$ aliquots were dispensed into Hungate tubes or serum bottles, respectively, under a stream of $\mathrm{N}_{2} / \mathrm{CO}_{2}(80: 20, \mathrm{v} / \mathrm{v})$ gas and the vessels were autoclaved for $45 \mathrm{~min}$ at $110^{\circ} \mathrm{C}$. Prior to inoculation, $\mathrm{Na}_{2} \mathrm{~S} .9 \mathrm{H}_{2} \mathrm{O}$ and $\mathrm{NaHCO}_{3}$ were injected from sterile stock solutions to final concentrations of 0.04 and $0.2 \%$, respectively. An aliquot of the water sample was inoculated into $20 \mathrm{ml}$ medium and incubated at $70{ }^{\circ} \mathrm{C}$ without agitation to initiate an enrichment culture. Several pure cultures were obtained by picking well isolated colonies that developed in the culture medium solidified with $4 \%$ (w/v) Phytagel (Sigma; Deming $\&$ Baross, 1986) by the repeated use of the Hungate rolltube method (Hungate, 1969). One of these was used for subsequent studies.

Characterization studies. $\mathrm{pH}$, temperature and $\mathrm{NaCl}$ ranges for growth were determined using the culture medium. The medium in Hungate tubes was adjusted to the desired $\mathrm{pH}$, measured at ambient temperature, by injecting $10 \%(\mathrm{w} / \mathrm{v})$ sterile anaerobic stock solutions of $\mathrm{NaHCO}_{3}$ or $\mathrm{Na}_{2} \mathrm{CO}_{3}$. $\mathrm{NaCl}$ was weighed directly in the tubes prior to dispensing the culture medium. The strain was subcultured at least once under the same experimental conditions prior to determination of growth rates. Substrates were tested in culture medium lacking glucose at a final concentration of $20 \mathrm{mM}$. To test for electron acceptors, sodium thiosulfate, sodium sulfate, sodium sulfite and elemental sulfur were added to the culture medium at final concentrations of $20 \mathrm{mM}$, $20 \mathrm{mM}, 2 \mathrm{mM}$ and $2 \%(\mathrm{w} / \mathrm{v})$, respectively.

Light and electron microscopy. Light microscopy was performed as described by Cayol et al. (1994). Electron microscopy was performed as described by Fardeau et al. (1997a).

Analytical techniques. Unless otherwise indicated, duplicate culture tubes were used throughout this study. Growth was measured by inserting tubes directly into a model UV-160A spectrophotometer (Shimadzu) and measuring changes in $\mathrm{OD}_{580}$. Sulfide was determined photometrically as colloidal $\mathrm{CuS}$ by using the method of Cord-Ruwisch (1985). $\mathrm{H}_{2}, \mathrm{CO}_{2}$, sugars, alcohols, volatile and non-volatile fatty acids were measured as described previously (Fardeau et al., 1996). LAlanine was measured by HPLC as described by Moore et al. (1958).

Determination of DNA $\mathbf{G}+\mathbf{C}$ content. The DNA $\mathrm{G}+\mathrm{C}$ content was determined by the DSMZ (Deutsche Sammlung von Mikroorganismen und Zellkulturen $\mathrm{GmbH}$, Braunschweig, Germany). DNA was isolated and purified by chromatography on hydroxyapatite and its $\mathrm{G}+\mathrm{C}$ content was determined by using HPLC as described by Mesbah et al. (1989). Non-methylated $\lambda$ DNA (Sigma) was used as the standard.

16S rDNA sequence analysis. The methods for the purification and extraction of DNA and the amplification and sequencing of the 16S rRNA gene have been described previously (Andrews \& Patel, 1996). The 16S rRNA gene sequence was manually aligned with reference sequences of various members of Bacteria using the editor ae2 (Maidak et al., 1999). Reference sequences were obtained from the Ribosomal Database Project (Maidak et al., 1999), EMBL and GenBank databases. Positions of sequence and alignment uncertainty were omitted from the analysis. The pairwise evolutionary distances based on 1224 unambiguous nucleotides were computed by using the method of Jukes \& Cantor (1969) and dendrograms were constructed from these distances by using the neighbour-joining method, both of which were from part of the PHYLIP suite of programs (Felsenstein, 1993). A maximum-likelihood approach with FastDNAml was used as an alternative method for tree construction (Olsen et al., 1994).

\section{RESULTS}

\section{Enrichment and isolation}

Enrichment cultures were positive after incubation at $70{ }^{\circ} \mathrm{C}$ for $3 \mathrm{~d}$ and $\mathrm{H}_{2} \mathrm{~S}$ was detected, presumably derived from thiosulfate reduction. Microscopic examination revealed the presence of rod-shaped bacteria. Single, well isolated colonies ( $3 \mathrm{~mm}$ diam.) that developed in Phytagel roll tubes after $3 \mathrm{~d}$ incubation at $70{ }^{\circ} \mathrm{C}$ were picked and serially diluted in Phytagel roll tubes at least twice before the culture was considered pure. Several axenic cultures were obtained and the culture designated strain SEBR $7858^{\mathrm{T}}$ was used for further studies.

\section{Morphology}

Strain SEBR $7858^{\mathrm{T}}$ was a rod-shaped bacterium $(0.5-0.7 \times 2-8 \mu \mathrm{m})$, which occurred singly (Fig. 1a). No motility was observed but the cells possessed laterally inserted peritrichous flagella (Fig. 1b). No spores were observed under microscopic examination (electron and light microscopy), but cultures exposed at $120^{\circ} \mathrm{C}$ for 45 min could be subcultured, suggesting the presence of heat-resistant forms. Electron microscopy of ultrathin sections revealed a Gram-positive cell wall composed of a thin dense surface layer separated from a thicker inner layer (Fig. 1c).

\section{Optimum growth conditions}

Strain SEBR $7858^{\mathrm{T}}$ was strictly anaerobic and did not grow in culture medium containing traces of oxygen, as indicated by the anaerobiosis indicator, resazurin. The strain grew optimally at $65^{\circ} \mathrm{C}$ (temperature range between 40 and $75^{\circ} \mathrm{C}$, but not at $80{ }^{\circ} \mathrm{C}$; Fig. 2a) and a $\mathrm{pH}$ of 7.5 (pH range between 6.0 and 8.5 ; Fig. 2b). The isolate grew in the presence of $0-3 \% \mathrm{NaCl}$ with an optimum of $0 \%$ at $\mathrm{pH} 7 \cdot 0$ and $70{ }^{\circ} \mathrm{C}$ (Fig. 2c).

\section{Substrates for growth}

Yeast extract or Bio-trypticase was required for growth on carbohydrates. Yeast extract could not be replaced by a vitamin mixture (Balch et al., 1979). 

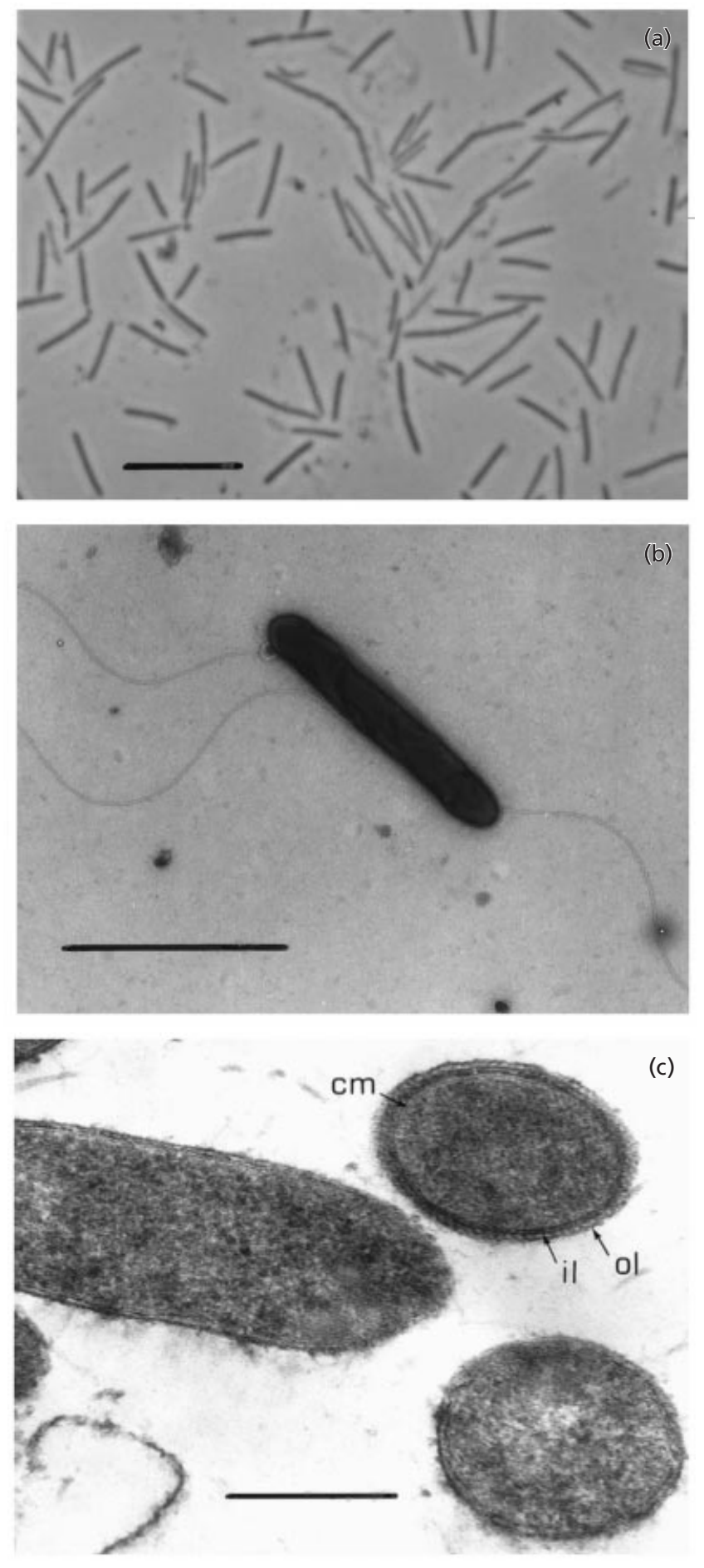

Fig. 1. (a) Phase-contrast micrograph of strain SEBR $7858^{\top}$. Bar, $10 \mu \mathrm{m}$. (b) Electron micrograph of a negatively stained culture of strain SEBR $7858^{\top}$ showing laterally inserted flagella. Bar, $2 \mu \mathrm{m}$. (c) Electron micrograph of an ultrathin section of strain SEBR $7858^{\top}$ showing the cytoplasmic membrane $(\mathrm{cm})$, the inner layer (il) and the outer layer (ol). Bar, $0.5 \mu \mathrm{m}$.

SEBR $7858^{\mathrm{T}}$ grew on the following substrates (at a concentration of $20 \mathrm{mM}$ unless otherwise indicated) in the presence of thiosulfate as the electron acceptor: D-
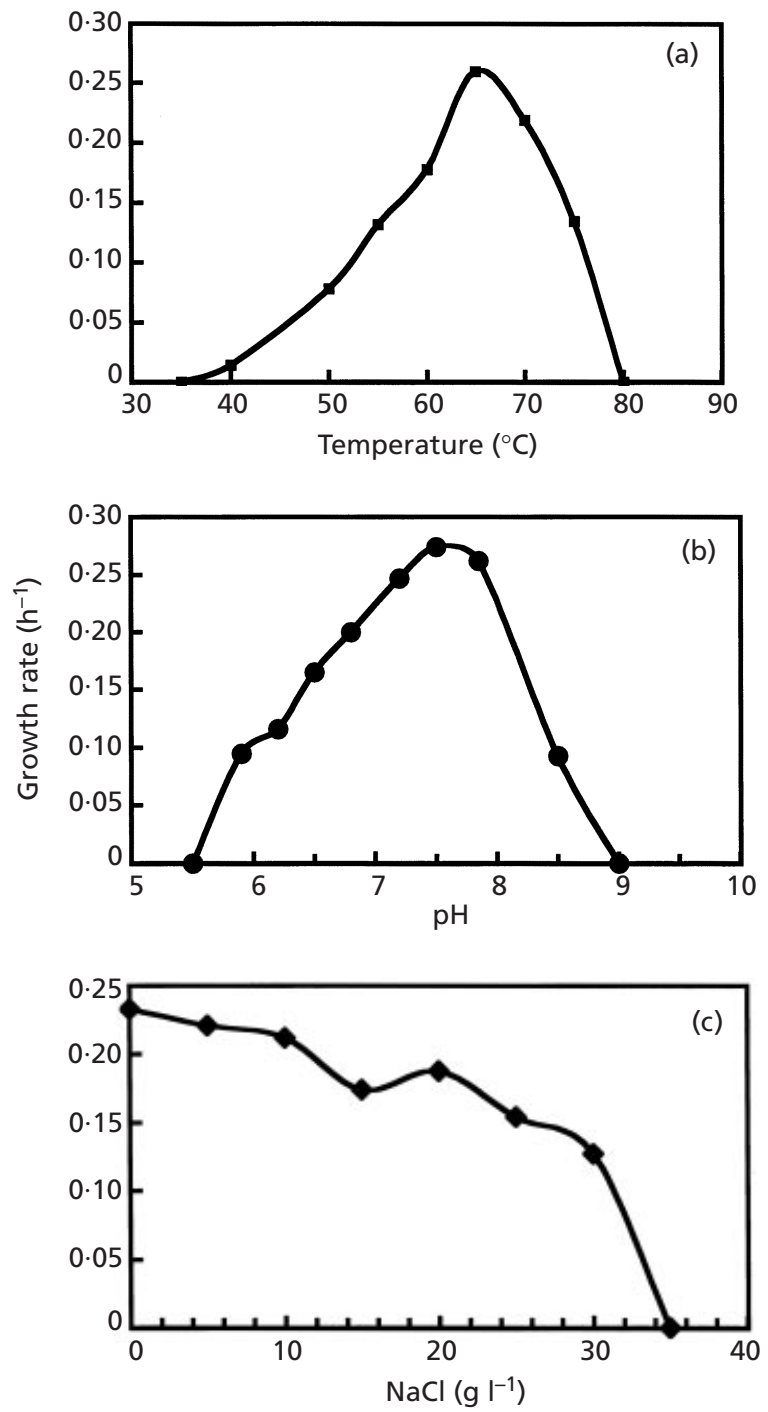

Fig. 2. Effect of (a) temperature $(\mathrm{pH} 7 \cdot 5$, no $\mathrm{NaCl})$, (b) $\mathrm{NaCl}$ $\left(65^{\circ} \mathrm{C}, \mathrm{pH} \mathrm{7.5)}\right.$ and (c) $\mathrm{pH}\left(65^{\circ} \mathrm{C}\right.$, no $\left.\mathrm{NaCl}\right)$ on the growth of strain SEBR $7858^{\top}$ cultivated in basal medium.

fructose, D-galactose, D-glucose, DL-lactose, DL-maltose, D-mannose, D-xylose, D-ribose, mannitol, cellobiose, pyruvate, melibiose, starch and xylan, but not Lxylose, L-arabinose, L-rhamnose, sorbose or sucrose. Glycerol was used poorly. Acetate, L-alanine, lactate, $\mathrm{H}_{2}$ and $\mathrm{CO}_{2}$ were produced from glucose fermentation. From 0.6 to $0.8 \mathrm{~mol} \mathrm{~L}$-alanine was produced per mole glucose consumed (Table 1).

\section{Effect of electron acceptors}

Strain SEBR $7858^{\mathrm{T}}$ reduced thiosulfate, elemental sulfur and sulfite, but not sulfate to sulfide. The presence of thiosulfate altered the concentration of metabolites during glucose oxidation, indicating that thiosulfate modified the metabolic pathway of strain 
Table 1. End products from glucose metabolism by Thermoanaerobacter subterraneus, in the presence or absence of thiosulfate $(20 \mathrm{mM})$

\begin{tabular}{|lcccccc|}
\hline Growth conditions & \multirow{2}{*}{$\begin{array}{c}\text { Amount of glucose } \\
\text { consumed (mmol) }\end{array}$} & \multicolumn{4}{c|}{ Amount of product (mmol)* } \\
\cline { 3 - 6 } & & Acetate & Lactate & L-Alanine & $\mathbf{H}_{\mathbf{2}}$ & $\mathbf{H}_{\mathbf{2}} \mathbf{S}$ \\
\hline Glucose & $9 \cdot 4$ & $10 \cdot 6$ & $1 \cdot 2$ & $8 \cdot 0$ & $5 \cdot 7$ & 0 \\
Glucose + thiosulfate & $8 \cdot 6$ & $20 \cdot 3$ & 0 & 0 & $0 \cdot 2$ & $21 \cdot 9$ \\
\hline
\end{tabular}

* Data were corrected for non-utilizable glucose present in the medium.

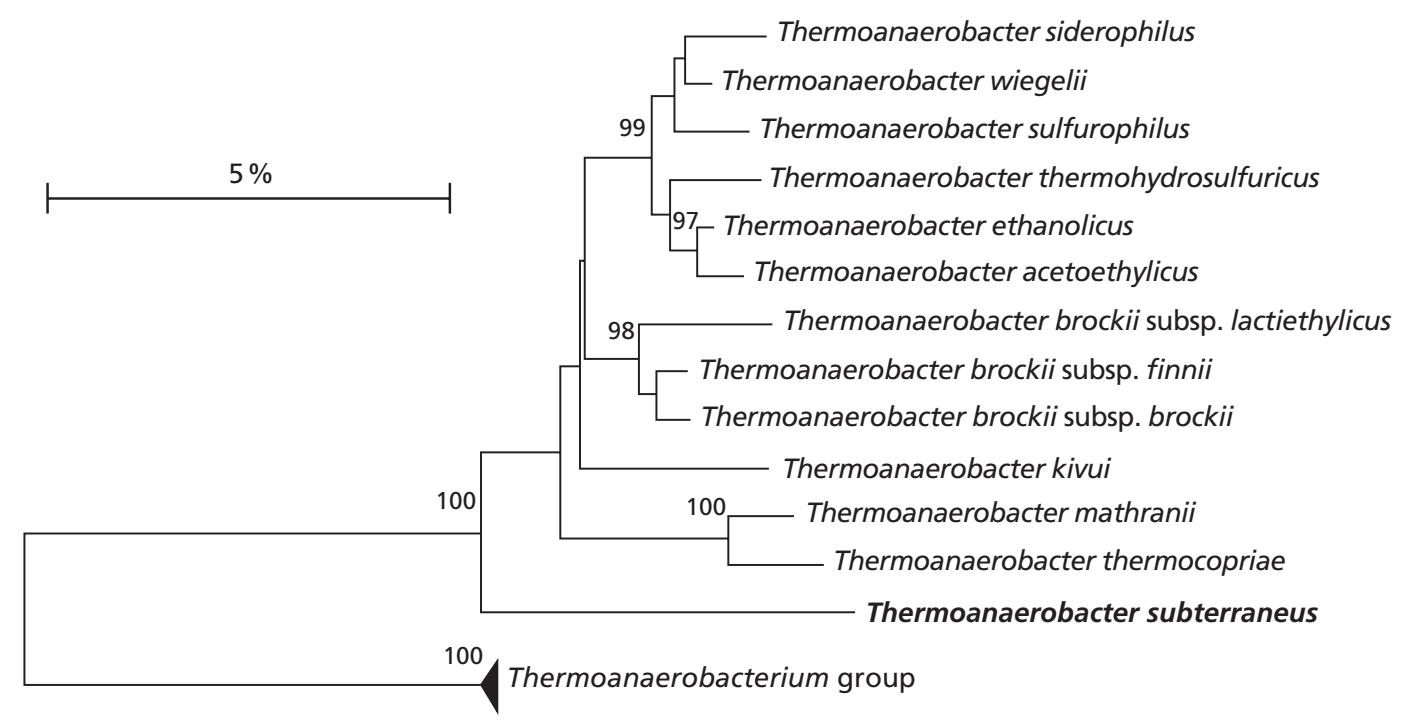

Fig. 3. Dendrogram indicating the position of strain SEBR $7858^{\top}$ amongst members of the genus Thermoanaerobacter. Sequences of the following type strains were obtained from the Ribosomal Database Project, version 7.0 (Maidak et al., 1999): Thermoanaerobacter acetoethylicus HTB2 $\mathrm{N}^{\top}$ (=ATCC $33265^{\top}$, DSM $\left.2359^{\top}\right)$, Thermoanaerobacter brockii subsp. brockii HTD4 $^{\top}$ (=ATCC $33075^{\top}$, DSM $\left.1457^{\top}\right)$, Thermoanaerobacter brockii subsp. finnii AKO-1 ${ }^{\top}\left(=\right.$ DSM $\left.^{3} 339^{\top}\right)$, Thermoanaerobacter brockii subsp. lactiethylicus SEBR $5268^{\top}\left(=\mathrm{DSM} 9801^{\top}\right)$, Thermoanaerobacter ethanolicus JW $200^{\top}$

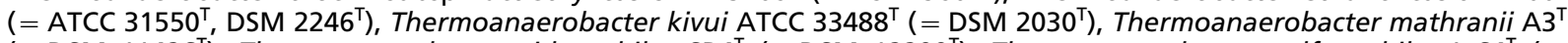
(= DSM 11426 $6^{\top}$, Thermoanaerobacter siderophilus SR4 ${ }^{\top}$ (= DSM 12299 $)$, Thermoanaerobacter sulfurophilus L-64 ${ }^{\top}(=$ DSM 11584 ${ }^{\top}$ ), Thermoanaerobacter thermocopriae $\left(=\right.$ IAM $\left.13577^{\top}\right)$, Thermoanaerobacter thermohydrosulfuricus E100$69^{\top}(=$ DSM 567 $)$, Thermoanaerobacter wiegelii Rt8.B1 $1^{\top}\left(=\right.$ DSM $\left.10319^{\top}\right)$. Bootstrap values, expressed as a percentage of 100 replications, are shown at branching points. Only values above $95 \%$ were considered significant and reported. Scale bar indicates 5 substitutions per $100 \mathrm{nt}$.

SEBR $7858^{\mathrm{T}}$. In the presence of thiosulfate, L-alanine was not detected, hydrogen production decreased, whereas sulfide production increased and acetate was the only acid detected (Table 1).

\section{S rDNA sequence analysis}

A total of $1372 \mathrm{nt}$ of the $16 \mathrm{~S}$ rDNA of strain SEBR $7858^{\mathrm{T}}$, corresponding to position $20-1470$ of the Escherichia coli $16 \mathrm{~S}$ rDNA, was sequenced. 16S rDNA sequence analysis and comparison with species representative of Bacteria indicated that strain SEBR $7858^{\mathrm{T}}$ was a member of the genus Thermoanaerobacter and formed a deep line of descent almost equidistant to the 12 taxonomically validated species and subspecies with available sequences, with a mean similarity of $93 \%$ (Fig. 3).

\section{DNA G + C content}

The $\mathrm{G}+\mathrm{C}$ content of isolate SEBR $7858^{\mathrm{T}}$ was $41 \mathrm{~mol} \%$ (as determined by HPLC).

\section{DISCUSSION}

Strains of various physiological groups of thermophilic bacteria have been previously isolated from deep subsurface environments such as oilfields and aquifers. In addition to methanogens and sulfate-reducing bacteria, heterotrophic micro-organisms, including members of the order Thermotogales and the family Thermoanaerobiaceae (e.g. the genus Thermoanaerobacter), have been isolated and described (Andrews \& Patel, 1996; Cayol et al., 1995; Fardeau et al., 1997a; Jeanthon et al., 1995; Magot et al., 2000; Ravot et al., 1995; Slobodkin et al., 1999; Stetter et al., 1993; 
Wynter et al., 1996). Strain SEBR $7858^{\mathrm{T}}$, a Grampositive thermophilic anaerobic bacterium, isolated from a French oilfield, is phylogenetically related to Thermoanaerobacter species. The presence of a Thermoanaerobacter species in oilfields was first reported in 1995. The isolate was found to be a phylogenetic relative of Thermoanaerobacter brockii and Thermoanaerobacter finnii (Cayol et al., 1995). It was recognized as a novel subspecies of the terrestrial microorganism Thermoanaerobacter brockii and named Thermoanaerobacter brockii subsp. lactiethylicus. Because of the large number of new isolates belonging to Thermoanaerobacter, the taxonomy of this genus was revised on the basis of $16 \mathrm{~S}$ rRNA sequence and DNA-DNA hybridization and now comprises 11 validated species, 3 subspecies and 3 non-validated species (Table 2).

The isolation of strain SEBR $7858^{\mathrm{T}}$ extends our knowledge on the diversity of microbes from subterrestrial ecosystems and confirms that Thermoanaerobacter species, similar to members of the order Thermotogales, may be important components of the heterotrophic microflora of oilfield reservoirs (Grassia et al., 1996; Magot et al., 2000). Studies on a methanogenic archaeon, Methanocalculus halotolerans isolated from an African oilfield (Ollivier et al., 1998), and the results reported by L'Haridon et al. (1995) suggest that indigenous micro-organisms might inhabit oilfield reservoirs. However, the presence of Thermoanaerobacter species in oilfield waters as a result of anthropogenic contamination rather than as an indigenous microflora cannot be ruled out entirely and further investigations are needed to understand their distribution. Nevertheless, Thermoanaerobacter species have a wide nutritional spectrum for growth, which includes carbohydrates and amino acids (Fardeau et al., 1997b; Faudon et al., 1995; Magot et al., 2000); oilfields may contain such nutrients, provided by other members of the bacterial community, that will possibly support their growth and/or viability.

Strain SEBR $7858^{\mathrm{T}}$ oxidizes hydrogen in the presence of sulfur compounds. This may lead to corrosion of oilfield installations when these latter compounds are available in oilfield waters. The presence of a hydrogen-oxidizing Thermoanaerobacter species was previously reported from oilfields (Fardeau et al., 1993a, b). In addition, thiosulfate reduction by Thermoanaerobacter species, including strain SEBR $7858^{\mathrm{T}}$, may be of significance in mineralization processes in thermal terrestrial or subterrestrial environments, since this reduction facilitates oxidation of organic matter as reported previously (Fardeau et al., 1996).

Strain SEBR $7858^{\mathrm{T}}$ has many features typical of some members of the genus Thermoanaerobacter. It is Grampositive, thermophilic (optimal temperature for growth is $65^{\circ} \mathrm{C}$ ), anaerobic and contains heat-resistant cells. The isolate reduces thiosulfate, sulfite and elemental sulfur, but not sulfate to sulfide. In addition, it ferments carbohydrates to L-alanine, acetate, lactate,
$\mathrm{H}_{2}$ and $\mathrm{CO}_{2}$. This constitutes the first experimental evidence of L-alanine production by a Thermoanaerobacter species. We have detected the presence of L-alanine from glucose fermentation in Thermoanaerobacter brockii and Thermoanaerobacter ethanolicus, but it is a minor product compared to strain SEBR $7858^{\mathrm{T}}$ (unpublished data). As for some members of Archaea (Kengen \& Stams, 1994; Kobayashi et al., 1995), L-alanine production from glucose metabolism has been reported in hyperthermophilic and thermophilic members of Bacteria (e.g. Thermotoga, Thermosipho and Fervidobacterium, order Thermotogales) and has been suggested to be a remnant of an ancestral metabolism (Ravot et al., 1996). L-Alanine is also produced by a Gram-positive anaerobe belonging to the genus Clostridium (Örlygsson et al., 1995). It is possible that L-alanine production from carbohydrate fermentation is more widespread amongst members of Bacteria than previously believed.

Strain SEBR $7858^{\mathrm{T}}$ differs from its closest phylogenetic relatives, such as Thermoanaerobacter brockii and Thermoanaerobacter ethanolicus, by fermenting melibiose and by using sucrose and xylose poorly. In contrast to Thermoanaerobacter brockii (Zeikus et al., 1979), strain SEBR $7858^{\mathrm{T}}$ has a much higher DNA $\mathrm{G}+\mathrm{C}$ content $\left(41 \%\right.$ for SEBR $7858^{\mathrm{T}}$ compared to $30-31 \%$ for Thermoanaerobacter brockii). The isolate also differs from Thermoanaerobacter ethanolicus (Wiegel \& Ljungdahl, 1981) as L-alanine is the major end product. Phylogenetic, genomic and phenotypic characteristics of strain SEBR $7858^{\mathrm{T}}$ confirm that it represents a new species of the genus Thermoanaerobacter for which we propose the name Thermoanaerobacter subterraneus sp. nov., reflecting its subterrestrial origin.

\section{Description of Thermoanaerobacter subterraneus sp. nov.}

Thermoanaerobacter subterraneus (sub.ter.ra'ne.us. L. pref. sub less than; L. n. terra earth; L. adj. subterraneus under the earth, describing its site of isolation).

Cells are rods $(0.5-0.7 \times 2-8 \mu \mathrm{m})$, occur singly or in pairs and possess laterally inserted flagella. Spores are not observed under microscopic examination but cultures exposed to $120^{\circ} \mathrm{C}$ for $45 \mathrm{~min}$ could be subcultured, suggesting the presence of heat-resistant forms. Electron microscopic examinations reveal a Gram-positive cell wall. Round colonies ( $3 \mathrm{~mm}$ diam.) develop in Phytagel roll tubes after $3 \mathrm{~d}$ incubation at $70{ }^{\circ} \mathrm{C}$. Chemo-organotrophic and obligately anaerobic member of the domain Bacteria. Optimum temperature for growth is $65^{\circ} \mathrm{C}$ at $\mathrm{pH} 7 \cdot 5$; temperature range for growth is $40-75^{\circ} \mathrm{C}$. Optimum $\mathrm{pH}$ is $7 \cdot 5$; growth occurs between $\mathrm{pH} 6.0$ and 8.5 . Halotolerant, growing in the presence of up to $3 \% \mathrm{NaCl}$. Yeast extract or Bio-trypticase is required for growth on carbohydrates. Growth on sugars is highly enhanced by the presence of both yeast extract and Bio-trypticase. Yeast extract cannot be replaced by vitamins. Fer- 
Table 2. Characteristics that differentiate members of the genus Thermoanaerobacter

Data were taken from the following sources for the following species: 1 , Thermoanaerobacter subterraneus, this study; 2 ,

'Thermoanaerobacter acetigenus', Nielsen et al. (1993); 3, Thermoanaerobacter acetoethylicus, Ben-Bassat \& Zeikus (1981); 4,

Thermoanaerobacter brockii subsp. brockii, Zeikus et al. (1979); 5, Thermoanaerobacter brockii subsp. finnii, Schmid et al. (1986);

6, Thermoanaerobacter brockii subsp. lactiethylicus, Cayol et al. (1995); 7, 'Thermoanaerobacter cellulolyticus', Taya et al. (1988);

8, Thermoanaerobacter ethanolicus, Wiegel \& Lungdahl (1981); 9, Thermoanaerobacter italicus, Kozianowski et al. (1997); 10,

\begin{tabular}{|c|c|c|c|c|c|c|c|c|}
\hline Character & 1 & 2 & 3 & 4 & 5 & 6 & 7 & 8 \\
\hline Type strain & DSM $13054^{\mathrm{T}}$ & DSM 7040 & DSM $2359^{\mathrm{T}}$ & DSM $1457^{\mathrm{T}}$ & DSM $3389^{\mathrm{T}}$ & DSM $9801^{\mathrm{T}}$ & DSM 8991 & DSM $2246^{\mathrm{T}}$ \\
\hline Source & Oil well & Hot spring & Hot spring & Hot spring & Lake Kivu & Oil well & Hot spring & Hot spring \\
\hline Temperature range $\left({ }^{\circ} \mathrm{C}\right)$ & $40-75$ & $50-78$ & $40-80$ & $35-85$ & $40-75$ & $40-75$ & $50-85$ & $37-78$ \\
\hline Optimum temperature $\left({ }^{\circ} \mathrm{C}\right)$ & 65 & $65-68$ & 65 & $65-70$ & $64-66$ & $55-60$ & 75 & 70 \\
\hline $\mathrm{pH}$ range & $6-8 \cdot 5$ & $5 \cdot 2-8 \cdot 6$ & $5 \cdot 5-8 \cdot 5$ & $5 \cdot 5-9 \cdot 5$ & ND & $5 \cdot 6-8 \cdot 8$ & $6-9 \cdot 5$ & $4 \cdot 4-9 \cdot 9$ \\
\hline Optimum $\mathrm{pH}$ & 7.5 & 7 & ND & $7 \cdot 5$ & $6 \cdot 5-6 \cdot 8$ & ND & $8-8 \cdot 3$ & $6-8$ \\
\hline $\mathrm{G}+\mathrm{C}$ content $(\mathrm{mol} \%)$ & 41 & $34 \cdot 9-36 \cdot 5$ & $30-32$ & $29-32 \cdot 4$ & 32 & 35 & 37.7 & $37-39$ \\
\hline Reduction of $\mathrm{S}^{\circ}$ & + & ND & - & - & $\mathrm{ND}$ & + & $\mathrm{ND}$ & ND \\
\hline Reduction of $\mathrm{S}_{2} \mathrm{O}_{2}^{2-}$ & + & - & + & + & + & + & ND & ND \\
\hline Flagella & Peritrichous & - & Peritrichous & - & Peritrichous & Peritrichous & Peritrichous & Peritrichous \\
\hline \multicolumn{9}{|l|}{ Substrates used: } \\
\hline Arabinose & - & + & - & - & ND & - & - & ND \\
\hline Cellobiose & + & + & + & + & + & + & + & + \\
\hline Fructose & + & + & ND & ND & + & + & + & + \\
\hline Galactose & + & + & ND & ND & + & + & + & + \\
\hline Glucose & + & + & + & + & + & + & + & + \\
\hline Inositol & $\mathrm{ND}$ & $\mathrm{ND}$ & ND & $\mathrm{ND}$ & ND & $\mathrm{ND}$ & - & - \\
\hline Lactose & + & + & + & + & + & + & + & + \\
\hline Maltose & + & + & + & + & + & + & + & + \\
\hline Mannitol & + & - & $\mathrm{ND}$ & ND & + & + & - & - \\
\hline Mannose & + & + & + & - & + & + & + & + \\
\hline Melezitose & $\mathrm{ND}$ & ND & ND & ND & $\mathrm{ND}$ & ND & - & - \\
\hline Melibiose & + & ND & ND & $\mathrm{ND}$ & ND & - & - & - \\
\hline Raffinose & $\mathrm{ND}$ & + & ND & ND & $\mathrm{ND}$ & $\mathrm{ND}$ & + & - \\
\hline Rhamnose & - & - & ND & $\mathrm{ND}$ & ND & - & - & - \\
\hline Ribose & + & - & $\mathrm{ND}$ & $\mathrm{ND}$ & + & + & - & + \\
\hline Starch & + & + & + & + & ND & + & + & + \\
\hline Sucrose & - & + & + & + & + & + & + & + \\
\hline Trehalose & $\mathrm{ND}$ & + & $\mathrm{ND}$ & $\mathrm{ND}$ & ND & $\mathrm{ND}$ & - & - \\
\hline Xylose & + & + & - & - & + & + & + & + \\
\hline Xylan & + & + & $\mathrm{ND}$ & ND & $\mathrm{ND}$ & $\mathrm{ND}$ & + & ND \\
\hline Formate & $\mathrm{ND}$ & ND & ND & ND & ND & ND & ND & ND \\
\hline Lactate & $\mathrm{ND}$ & - & - & - & $\mathrm{ND}$ & ND & $\mathrm{ND}$ & ND \\
\hline Pyruvate & + & - & - & + & + & + & $\mathrm{ND}$ & + \\
\hline Beef extract & $\mathrm{ND}$ & $\mathrm{ND}$ & ND & ND & $\mathrm{ND}$ & ND & ND & $\mathrm{ND}$ \\
\hline Tryptone & ND & $\mathrm{ND}$ & + & - & $\mathrm{ND}$ & ND & ND & ND \\
\hline Yeast extract & $\mathrm{ND}$ & - & + & ND & $\mathrm{ND}$ & + & ND & $\mathrm{ND}$ \\
\hline Amygdalin & ND & ND & ND & ND & $\mathrm{ND}$ & ND & - & - \\
\hline Cellulose & ND & - & ND & - & ND & - & + & - \\
\hline Chitin & $\mathrm{ND}$ & $\mathrm{ND}$ & $\mathrm{ND}$ & ND & ND & $\mathrm{ND}$ & $\mathrm{ND}$ & $\mathrm{ND}$ \\
\hline Aesculin & ND & $\mathrm{ND}$ & ND & ND & $\mathrm{ND}$ & $\mathrm{ND}$ & - & + \\
\hline Glucosamine & $\mathrm{ND}$ & ND & ND & ND & ND & ND & ND & $\mathrm{ND}$ \\
\hline Glycerol & + & $\mathrm{ND}$ & ND & ND & ND & - & - & - \\
\hline Glycogen & ND & ND & ND & ND & $\mathrm{ND}$ & ND & - & ND \\
\hline Hemicellulose & ND & $\mathrm{ND}$ & ND & ND & ND & ND & ND & ND \\
\hline Inulin & $\mathrm{ND}$ & ND & ND & ND & $\mathrm{ND}$ & $\mathrm{ND}$ & - & ND \\
\hline Pectin & ND & ND & - & - & ND & ND & - & ND \\
\hline $\begin{array}{l}\text { Diagnostic fermentation } \\
\text { products from glucose* }\end{array}$ & $\begin{array}{l}\text { Ethanol, } \\
\text { lactate, } \\
\text { L-alanine }\end{array}$ & $\begin{array}{l}\text { Ethanol, } \\
\text { isobutyrate }\end{array}$ & $\begin{array}{c}\text { Ethanol, } \\
\text { isobutyrate, } \\
\text { butyrate, } \\
\text { isovalerate, } \\
\text { valerate }\end{array}$ & $\begin{array}{l}\text { Ethanol, } \\
\text { lactate }\end{array}$ & $\begin{array}{l}\text { Ethanol, } \\
\text { lactate }\end{array}$ & Ethanol & Lactate & $\begin{array}{l}\text { Ethanol, } \\
\text { lactate }\end{array}$ \\
\hline
\end{tabular}

* All species tested produced acetate, $\mathrm{H}_{2}$ and $\mathrm{CO}_{2}$ with the exception of Thermoanaerobacter siderophilus which did not produce acetate.

$\dagger$ Homoacetogenic species. 
Table 2 (cont)

Thermoanaerobacter kivui, Zeikus et al. (1979); 11, 'Thermoanaerobacter lactoethylicus', Kondratieva et al. (1989); 12,

Thermoanaerobacter mathranii, Larsen et al. (1997); 13, Thermoanaerobacter siderophilus, Slobodkin et al. (1999); 14,

Thermoanaerobacter sulfurophilus, Bonch-Osmolovskaya et al. (1997); 15, Thermoanaerobacter thermocopriae, Jin et al. (1988); 16, Thermoanaerobacter thermohydrosulfuricus, Wiegel et al. (1979); 17, Thermoanaerobacter wiegelii, Cook et al. (1996). ND, Not determined.

\begin{tabular}{|c|c|c|c|c|c|c|c|c|}
\hline 9 & 10 & 11 & 12 & 13 & 14 & 15 & 16 & 17 \\
\hline DSM $9252^{\mathrm{T}}$ & DSM $2030^{\mathrm{T}}$ & DSM 9003 & DSM $11426^{\mathrm{T}}$ & DSM $12299^{\mathrm{T}}$ & DSM $11584^{\mathrm{T}}$ & IAM $13577^{\mathrm{T}}$ & DSM $567^{\mathrm{T}}$ & DSM $10319^{T}$ \\
\hline Hot spring & Lake Kivu & Hot spring & Hot spring & $\begin{array}{l}\text { Hydrothermal } \\
\text { vent }\end{array}$ & $\begin{array}{c}\text { Cyanobacterial } \\
\text { mats }\end{array}$ & Hot spring & Hot spring & $\begin{array}{l}\text { Geothermal } \\
\text { water }\end{array}$ \\
\hline $45-78$ & $50-72$ & $42-75$ & $47-78$ & 39-78 & 44-75 & $47-74$ & $40-78$ & 38-78 \\
\hline 70 & 66 & 65 & $70-75$ & $69-71$ & $55-60$ & 60 & 68 & $65-68$ \\
\hline ND & $5 \cdot 3-7 \cdot 3$ & $5-8 \cdot 5$ & $4 \cdot 7-8 \cdot 8$ & $4 \cdot 8-8 \cdot 2$ & $4 \cdot 5-8$ & $6-8$ & $5-9$ & $5 \cdot 5-7 \cdot 2$ \\
\hline 7 & $6 \cdot 4$ & 7 & $6 \cdot 8-7 \cdot 8$ & $6 \cdot 3-6 \cdot 5$ & $6 \cdot 8-7 \cdot 2$ & $6 \cdot 5-7 \cdot 3$ & $6 \cdot 9-7 \cdot 5$ & 6.8 \\
\hline $34 \cdot 4$ & 38 & $34 \cdot 6$ & 37 & 32 & $29 \cdot 8-30 \cdot 8$ & $6 \cdot 7-37.8$ & $37 \cdot 6$ & $34 \cdot 4-36 \cdot 8$ \\
\hline- & $\mathrm{ND}$ & + & + & + & + & ND & - & - \\
\hline+ & ND & ND & + & + & + & $\mathrm{ND}$ & + & + \\
\hline - & - & - & Peritrichous & Peritrichous & Peritrichous & ND & Lateral & Peritrichous \\
\hline+ & ND & + & + & - & + & + & + & - \\
\hline+ & - & + & + & + & + & + & + & + \\
\hline+ & + & + & + & + & + & + & + & + \\
\hline+ & - & + & - & ND & ND & - & + & + \\
\hline+ & + & + & + & + & + & + & + & + \\
\hline $\mathrm{ND}$ & - & $\mathrm{ND}$ & $\mathrm{ND}$ & $\mathrm{ND}$ & + & ND & - & - \\
\hline+ & - & + & + & ND & + & + & $\mathrm{ND}$ & + \\
\hline+ & - & + & + & + & + & + & + & + \\
\hline $\mathrm{ND}$ & - & + & + & ND & + & - & ND & + \\
\hline+ & + & ND & + & $\mathrm{ND}$ & ND & + & + & + \\
\hline+ & ND & $\mathrm{ND}$ & + & ND & ND & - & ND & - \\
\hline+ & ND & $\mathrm{ND}$ & + & ND & $\mathrm{ND}$ & - & ND & - \\
\hline+ & - & $\mathrm{ND}$ & + & ND & ND & - & + & + \\
\hline ND & $\mathrm{ND}$ & + & - & $\mathrm{ND}$ & + & - & + & - \\
\hline $\mathrm{ND}$ & - & ND & + & $\mathrm{ND}$ & ND & - & + & - \\
\hline+ & ND & ND & - & + & + & - & - & + \\
\hline+ & - & + & $\mathrm{ND}$ & + & + & - & + & + \\
\hline+ & - & + & + & + & + & - & + & + \\
\hline+ & - & ND & + & ND & ND & + & ND & + \\
\hline+ & ND & + & + & + & + & ND & + & + \\
\hline ND & ND & $\mathrm{ND}$ & + & - & $\mathrm{ND}$ & - & $\mathrm{ND}$ & - \\
\hline ND & + & $\mathrm{ND}$ & ND & - & - & ND & $\mathrm{ND}$ & $\mathrm{ND}$ \\
\hline ND & - & $\mathrm{ND}$ & ND & - & + & ND & ND & - \\
\hline $\mathrm{ND}$ & + & ND & ND & + & + & ND & + & - \\
\hline $\mathrm{ND}$ & ND & ND & $\mathrm{ND}$ & + & ND & ND & ND & ND \\
\hline $\mathrm{ND}$ & ND & ND & ND & + & ND & ND & ND & ND \\
\hline+ & ND & ND & - & + & ND & ND & ND & ND \\
\hline - & ND & ND & + & ND & ND & + & ND & ND \\
\hline $\mathrm{ND}$ & - & $\mathrm{ND}$ & - & - & - & + & ND & $\mathrm{ND}$ \\
\hline+ & $\mathrm{ND}$ & ND & $\mathrm{ND}$ & ND & ND & ND & ND & + \\
\hline+ & ND & $\mathrm{ND}$ & $\mathrm{ND}$ & ND & $\mathrm{ND}$ & $\mathrm{ND}$ & ND & $\mathrm{ND}$ \\
\hline $\mathrm{ND}$ & $\mathrm{ND}$ & ND & $\mathrm{ND}$ & ND & ND & ND & - & + \\
\hline+ & - & $\mathrm{ND}$ & - & + & $\mathrm{ND}$ & ND & - & + \\
\hline - & ND & ND & + & ND & ND & + & $\mathrm{ND}$ & $\mathrm{ND}$ \\
\hline+ & $\mathrm{ND}$ & $\mathrm{ND}$ & $\mathrm{ND}$ & ND & $\mathrm{ND}$ & + & $\mathrm{ND}$ & ND \\
\hline+ & ND & ND & - & ND & ND & - & ND & $\mathrm{ND}$ \\
\hline $\begin{array}{l}\text { Ethanol, } \\
\text { lactate, } \\
\text { succinate }\end{array}$ & Acetate $\dagger$ & $\begin{array}{c}\text { Ethanol, } \\
\text { lactate, } \\
\text { propionate, } \\
\text { butyrate, } \\
\text { isovalerate }\end{array}$ & $\begin{array}{l}\text { Ethanol, } \\
\text { lactate }\end{array}$ & $\begin{array}{l}\text { Ethanol, } \\
\text { lactate }\end{array}$ & $\begin{array}{l}\text { Ethanol, } \\
\text { lactate }\end{array}$ & $\begin{array}{c}\text { Ethanol, } \\
\text { butyrate, } \\
\text { lactate }\end{array}$ & $\begin{array}{l}\text { Ethanol, lactate, } \\
\text { formate, propanol, } \\
\text { 2-propanol, } \\
\text { butyrate, } \\
\text { isovalerate, } \\
\text { isocaproate }\end{array}$ & $\begin{array}{l}\text { Ethanol, } \\
\text { lactate, } \\
\text { propionate }\end{array}$ \\
\hline
\end{tabular}


ments cellobiose, D-fructose, D-galactose, D-glucose, DL-lactose, DL-maltose, D-mannose, melibiose, Dribose, starch, D-xylose, mannitol, pyruvate and xylan. Glycerol is poorly utilized and L-arabinose, L-rhamnose, sorbose, sucrose and L-xylose are not used. Acetate, L-alanine, lactate, $\mathrm{H}_{2}$ and $\mathrm{CO}_{2}$ are produced during glucose fermentation. Elemental sulfur, thiosulfate and sulfite, but not sulfate, are used as electron acceptor. The DNA G $+\mathrm{C}$ content is $41 \mathrm{~mol} \%$ (as determined by HPLC). Isolated from oilfield water. Type strain is SEBR $7858^{\mathrm{T}}\left(=\mathrm{CNCM} \mathrm{I-2383^{ \textrm {T } }}\right.$, DSM $\left.13054^{\mathrm{T}}\right)$.

\section{ACKNOWLEDGEMENTS}

ELF Aquitaine is acknowledged for its financial support to M.M. and for authorizing the publication of this manuscript. The financial assistance in part to B.K.C.P. from the Australian Research Council is gratefully acknowledged. We thank M. Camoin for technical assistance and P. A Roger for improving the manuscript.

\section{REFERENCES}

Andrews, K. T. \& Patel, B. K. C. (1996). Fervidobacterium gondwanense sp. nov., a new thermophilic anaerobic bacterium isolated from nonvolcanically heated geothermal waters of the Great Artesian Basin of Australia. Int J Syst Bacteriol 46, 265-269.

Balch, W. E., Fox, G. E., Magrum, R. J. \& Wolfe, R. S. (1979). Methanogens: re-evaluation of a unique biological group. Microbiol Rev 43, 260-296.

Ben-Bassat, A. \& Zeikus, J. G. (1981). Thermobacteroides acetoethylicus gen. nov., spec. nov., a new chemoorganotrophic, anaerobic, thermophilic bacterium. Arch Microbiol 128, 365370

Bernard, F. P., Connan, J. \& Magot, M. (1992). Indigenous microorganisms in connate water of many oil fields: a new tool in exploration and production techniques. In $S P E 24811$. Proceedings of the Society of Petroleum Engineers, vol. 2, pp. 467-475. Richardson, TX: Society of Petroleum Engineers.

Bonch-Osmolovskaya, E. A., Miroshnichenko, M. L., Chernykh, N. A., Kostrikina, N. A., Pikuta, E. V. \& Rainey, F. A. (1997). Reduction of elemental sulfur by moderately thermophilic organotrophic bacteria and the description of Thermoanaerobacter sulfurophilus sp. nov. Microbiology (English translation of Mikrobiologiya) 66, 581-587.

Cayol, J.-L., Ollivier, B., Lawson Anani Soh, A., Fardeau, M.-L. Ageron, E., Grimont, P. A. D., Prensier, G., Guezennec, J., Magot, M. \& Garcia, J.-L. (1994). Haloincola saccharolytica subsp. senegalensis subsp. nov., isolated from the sediments of a hypersaline lake, and emended description of Haloincola saccharolytica. Int $J$ Syst Bacteriol 44, 805-811.

Cayol, J.-L., Ollivier, B., Patel, B. K. C., Ravot, G., Magot, M., Ageron, E., Grimont, P. A. D. \& Garcia, J.-L. (1995). Description of Thermoanaerobacter brockii subsp. lactiethylicus subsp. nov., isolated from a deep subsurface French oil well, a proposal to reclassify Thermoanaerobacter finnii as Thermoanaerobacter brockii subsp. finnii comb. nov., and emended description of Thermoanaerobacter brockii. Int J Syst Bacteriol 45, 783-789.

Cook, G. M., Rainey, F. A., Patel, B. K. C. \& Morgan, H. W. (1996). Characterization of a new obligately anaerobic thermophile, Thermoanaerobacter wiegelii sp. nov. Int J Syst Bacteriol 46, 123-127.
Cord-Ruwisch, R. (1985). A quick method for the determination of dissolved and precipitated sulfides in cultures of sulfatereducing bacteria. J Microbiol Methods 4, 33-36.

Deming, J. W. \& Baross, J. A. (1986). Solid medium for culturing black smoker bacteria at temperature to $120^{\circ} \mathrm{C}$. Appl Environ Microbiol 51, 238-243.

Fardeau, M.-L., Cayol, J.-L., Magot, M. \& Ollivier, B. (1993a). $\mathrm{H}_{2}$ oxidation in the presence of thiosulfate by a Thermoanaerobacter strain isolated from an oil-producing well. FEMS Microbiol Lett 113, 327-332.

Fardeau, M.-L., Cayol, J.-L., Magot, M. \& Ollivier, B. (1993b). Hydrogen oxidation abilities in the presence of thiosulfate as electron acceptor within the genus Thermoanaerobacter. Curr Microbiol 29, 269-272.

Fardeau, M.-L., Faudon, C., Cayol, J.-L., Magot, M., Patel, B. K. C. \& Ollivier, B. (1996). Effect of thiosulfate as electron acceptor on glucose and xylose oxidation by Thermoanaerobacter finnii and a Thermoanaerobacter sp. isolated from oil field water. Res Microbiol 147, 159-165.

Fardeau, M.-L., Ollivier, B., Patel, B. K. C., Magot, M., Thomas, P., Rimbault, A., Rocchiccioli, F. \& Garcia, J.-L. (1997a). Thermotoga hypogea sp. nov., a xylanolytic, thermophilic bacterium from an oil-producing well. Int J Syst Bacteriol 47, 1013-1019.

Fardeau, M.-L., Patel, B. K. C., Magot, M. \& Ollivier, B. (1997b). Utilization of serine, isoleucine, and valine by Thermoanaerobacter brockii in the presence of thiosulfate or Methanobacterium sp. as electron acceptors. Anaerobe 3, 405-410.

Faudon, C., Fardeau, M.-L., Heim, J., Patel, B. K. C., Magot, M. \& Ollivier, B. (1995). Peptide and amino acid oxidation in the presence of thiosulfate by members of the genus Thermoanaerobacter. Curr Microbiol 31, 152-157.

Felsenstein, J. (1993). PHYLIP (Phylogeny Inference Package) version 3.5.1. Seattle: Department of Genetics, University of Washington.

Grassia, G. S., McLean, K. M., Glénat, P., Bauld, J. \& Sheehy, A. J. (1996). A systematic survey for thermophilic fermentative bacteria and archaea in high temperature petroleum reservoirs. FEMS Microbiol Ecol 21, 47-58.

Hungate, R. E. (1969). A roll-tube method for the cultivation of strict anaerobes. Methods Microbiol 3B, 117-132.

Jeanthon, C., Reysenbach, A. L., L'Haridon, S., Gambacorta, A., Pace, N. R., Glénat, P. \& Prieur, D. (1995). Thermotoga subterranea sp. nov., a new thermophilic bacterium isolated from a continental oil reservoir. Arch Microbiol 164, 91-97.

Jin, F., Yamasato, K. \& Kiyoshi, T. (1988). Clostridium thermocopriae sp. nov., a cellulolytic thermophile from animal feces, compost, soil and a hot spring in Japan. Int J Syst Bacteriol 38, 279-281.

Jukes, T. H. \& Cantor, C. R. (1969). Evolution of protein molecules. In Mammalian Protein Metabolism, pp. 21-132. Edited by H. N. Munro. New York: Academic Press.

Kengen, S. W. M. \& Stams, A. J. M. (1994). Formation of Lalanine as a reduced end product in carbohydrate fermentation by the hyperthermophilic archaeon Pyrococcus furiosus. Arch Microbiol 161, 168-175.

Kobayashi, T., Higuchi, S., Kimura, K., Kudo, T. \& Horikoshi, K. (1995). Properties of glutamate dehydrogenase and its involvement in alanine production in a thermophilic archaeon, Thermococcus profundus. J Biochem 118, 587-592.

Kondratieva, E. N., Zacharova, E. V., Duda, V. I. \& Krivenko, V. V. (1989). Thermoanaerobium lactoethylicum spec. nov., a new 
anaerobic bacterium from a hot spring of Kamchatka. Arch Microbiol 151, 117-122.

Kozianowski, G., Canganella, F., Rainey, F. A., Hippe, H. \& Antranikian, G. (1997). Purification and characterization of thermostable pectate-lyases from a newly isolated thermophilic bacterium, Thermoanaerobacter italicus sp. nov. Extremophiles 1, 171-182.

Larsen, L., Nielsen, P. \& Ahring, B. K. (1997). Thermoanaerobacter mathranii sp. nov., an ethanol-producing, extremely thermophilic anaerobic bacterium from a hot spring in Iceland. Arch Microbiol 168, 114-119.

Lee, Y. E., Jain, M. K., Lee, C., Lowe, S. E. \& Zeikus, J. G. (1993). Taxonomic distinction of saccharolytic thermophilic anaerobes: description of Thermoanaerobacterium xylanolyticum gen. nov., sp. nov., and Thermoanaerobacterium saccharolyticum gen. nov., sp. nov.; reclassification of Thermoanaerobium brockii, Clostridium thermosulfurogenes, and Clostridium thermohydrosulfuricum E100-69 as Thermoanaerobacter brockii comb. nov., Thermoanaerobacterium thermosulfurigenes comb. nov., and Thermoanaerobacter thermohydrosulfuricus comb. nov., respectively; and transfer of Clostridium thermohydrosulfuricum 39E to Thermoanaerobacter ethanolicus. Int J Syst Bacteriol 43, 41-51.

Leigh, J. A., Mayer, F. \& Wolfe, R. S. (1981). Acetogenium kivui, a new thermophilic hydrogen-oxidizing, acetogenic bacterium. Arch Microbiol 129, 275-280.

L'Haridon, S., Reysenbach, A. L., Glénat, P., Prieur, D. \& Jeanthon, C. (1995). Hot subterranean biosphere in a continental oil reservoir. Nature 377, 223-224.

Magot, M., Ollivier, B. \& Patel, B. K. C. (2000). Microbiology of petroleum reservoirs. Antonie Leeuwenhoek 77, 103-116.

Maidak, B. L., Cole, J. R., Parker, C. T., Jr \& 11 other authors (1999). A new version of the RDP (Ribosomal Database Project) Nucleic Acids Res 27, 171-173.

Mesbah, M., Premachandran, U. \& Whitman, W. B. (1989). Precise measurement of the $\mathrm{G}+\mathrm{C}$ content of deoxyribonucleic acid by high-performance liquid chromatography. Int J Syst Bacteriol 39, 159-167.

Moore, S., Spackman, D. H. \& Stein, W. H. (1958). Chromatography of amino acids on sulfonated polystyrene resins: an improved system. Anal Chem 30, 1185-1190.

Nielsen, P., Mathrani, I. M. \& Ahring, B. K. (1993). Thermoanaerobium acetigenum spec. nov., a new anaerobic, extremely thermophilic, xylanolytic non-spore-forming bacterium isolated from an Icelandic hot spring. Arch Microbiol 159, 460-464.

Ollivier, B., Fardeau, M.-L., Cayol, J.-L., Magot, M., Patel, B. K. C., Prensier, G. \& Garcia, J.-L. (1998). Characterization of Methanocalculus halotolerans gen. nov., sp. nov., isolated from an oilproducing well. Int J Syst Bacteriol 48, 821-828.
Olsen, G. J., Matsuda, H., Hagstrom, R. \& Overbeek, R. (1994). FastDNAml: a tool for construction of phylogenetic trees of DNA sequences using maximum likelihood. CABIOS 10, 41-48.

Örlygsson, J., Anderson, R. \& Svensson, B. H. (1995). Alanine as an end product during fermentation of monosaccharides by Clostridium strain P2. Antonie Leeuwenhoek 68, 273-280.

Ravot, G., Magot, M., Fardeau, M.-L., Patel, B. K. C., Prensier, G., Egan, A., Garcia, J.-L. \& Ollivier, B. (1995). Thermotoga elfii sp. nov., a novel thermophilic bacterium from an African oilproducing well. Int J Syst Bacteriol 45, 308-314.

Ravot, G., Ollivier, B., Fardeau, M.-L., Patel, B. K. C., Andrews, K. T., Magot, M. \& Garcia, J.-L. (1996). L-Alanine production from glucose fermentation by hyperthermophilic members of the domains Bacteria and Archaea: a remnant of an ancestral metabolism. Appl Environ Microbiol 62, 2657-2659.

Schmid, U., Giesel, H., Schoberth, S. M. \& Sahm, H. (1986). Thermoanaerobacter finnii spec. nov, a new ethanologenic sporogenous bacterium. Syst Appl Microbiol 8, 80-85.

Slobodkin, A. I., Tourova, T. P., Kuznetsov, B. B., Kostrikina, N. A., Chernyh, N. A. \& Bonch-Osmolovskaya, E. A. (1999). Thermoanaerobacter siderophilus sp. nov., a novel dissimilatory $\mathrm{Fe}(\mathrm{III})$-reducing, anaerobic, thermophilic bacterium. Int J Syst Bacteriol 49, 1471-1478.

Stetter, K. O., Huber, R., Blöchl, E., Kurr, M., Eden, R. D., Fielder, M., Cash, H. \& Vance, I. (1993). Hyperthermophilic archaea are thriving in deep North Sea and Alaskan oil reservoirs. Nature 365, 743-745.

Taya, M., Hinoki, H., Yagi, T. \& Kobayashi, T. (1988). Isolation and characterization of an extremely thermophilic, cellulolytic, anaerobic bacterium. Appl Microbiol Biotechnol 29, 474-479.

Wiegel, J. (1986). Genus Thermoanaerobacter. In Bergey's Manual of Systematic Bacteriology, vol. 2, pp. 1379-1383. Edited by P. H. A. Sneath, N. S. Mair, M. E. Sharpe \& J. G. Holt. Baltimore: Williams \& Wilkins.

Wiegel, J. \& Ljungdahl, L. G. (1981). Thermoanaerobacter ethanolicus gen. nov., sp. nov., a new extreme thermophilic, anaerobic bacterium. Arch Microbiol 128, 343-348.

Wiegel, J., Ljungdahl, L. G. \& Rawson, J. R. (1979). Isolation from soil and properties of the extreme thermophile Clostridium thermohydrosulfuricum. J Bacteriol 139, 800-810.

Wynter, C., Patel, B. K. C., Bain, P., De Jersey, J., Hamilton, S. \& Inkerman, P. A. (1996). A novel thermostable dextranase from a Thermoanaerobacter species cultured from the geothermal waters of the Great Artesian Basin of Australia. FEMS Microbiol Lett 140, 271-276.

Zeikus, J. G., Hegge, P. W. \& Anderson, M. A. (1979). Thermoanaerobium brockii gen. nov. and sp. nov., a new chemoorganotrophic, caldoactive, anaerobic bacterium. Arch Microbiol 122, 41-48. 